\title{
Corollary of Energy Transfer On Luminescence From Ce3+ / Eu3+ Co-Activated Glasses For White Light- Emitting Diodes
}

Keywords:

Posted Date: April 8th, 2021

DOI: https://doi.org/10.21203/rs.3.rs-376933/v2

License: (c) (1) This work is licensed under a Creative Commons Attribution 4.0 International License. Read Full License 


\section{Abstract}

The authors have requested that this preprint be removed from Research Square. 